\title{
Regio- and stereo-selective coupling reactions of heteroarylalkyl propargyl ethers with electrophiles
}

\author{
Saverio Florio, ${ }^{b}{ }^{b}$ Catia Granito, ${ }^{a}$ Giovanni Ingrosso, ${ }^{a}$ and Luigino Troisi ${ }^{a}$ \\ ${ }^{a}$ Dipartimento di Scienze e Tecnologie Biologiche ed Ambientali, University of Lecce, Via \\ Prov.le Lecce-Monteroni, 73100 Lecce, Italy, and ${ }^{b}$ CNR “Istituto di Chimica dei Composti \\ Organometallici - I.C.C.O.M.” Sezione di Bari, Dipartimento Farmaco-Chimico, University of \\ Bari, Via E. Orabona 4, 70125 Bari, Italy \\ E-mail: luigino.troisi@unile.it
}

Dedicated to Professor Mimmo Spinelli on his $70^{\text {th }}$ birthday

(received 15 Oct 02; accepted 26 Dec 02; published on the web 03 Jan 03)

\begin{abstract}
Treatment of heteroarylalkyl propargyl ethers with $n$-BuLi affords relatively stable $\alpha$ - and $\alpha^{\prime}$ carbanions. Deprotonation performed in the presence of electrophiles leads to heteroarylsubstituted propargylic ethers and hydroxyalkylpropargylic ethers, containing new stereogenic centers. When the same reactions were carried out in the presence of an external chiral ligand, fairly good asymmetric induction was observed.
\end{abstract}

Keywords: Heterocycles, C-C coupling, heteroarylalkyl propargyl ethers, hydroxyalkyl propargylic ethers

\section{Introduction}

Carbanions $\alpha$ - to an aza- heterocycle are known to be relatively stable. ${ }^{1}$ More interesting in synthetic organic chemistry are those carbanions which possess a further electron-withdrawing group. $\alpha$-Chlorocarbenoids, prepared by deprotonation of the corresponding $\alpha$-chloro-heteroarylalkanes, have been widely exploited as key intermediates in the synthesis of oxiranes ${ }^{2}$ and aziridines. $^{2 c, 3}$ Less studied as synthetic intermediates are those hetero-substituted carbenoids which possess in their framework an oxygen, ${ }^{4,5}$ a nitrogen, or a sulfur atom other than in the heterocycle.

We have recently shown that deprotonation ( $n$-BuLi, THF at $-78^{\circ} \mathrm{C}$ ) of heteroarylalkyl propargyl ethers followed by acidic quenching leads to propargylic and allenic alcohols as a result of competitive [1,2]- and [2,3]-Wittig sigmatropic rearrangements. ${ }^{4}$ We have also reported that deprotonated allyl heteroarylalkyl ethers afford allylic and homoallylic alcohols. ${ }^{5}$ Such 
rearrangements are likely to proceed by the same mechanisms, ${ }^{6}$ and specifically those reported by Nakai et al. ${ }^{6 \mathrm{~d}, \mathrm{e}, 7}$ for analogous substrates, so that the [2,3]-Wittig rearrangement product would be the outcome of the $\alpha$-carbon- atom deprotonation, while the [1,2]-Wittig rearrangement product would result from the deprotonation at the $\alpha^{\prime}$-carbon atom. The deprotonation occurred at the $\alpha$ - or at the $\alpha$-carbon atom depending on the acidifying effect of the substituents on the ether substrate. Our interest in the proposed mechanisms prompted us to investigate the behavior of heteroarylalkyl propargyl ethers when deprotonated in the presence of electrophiles. In this paper we report on the deprotonation of the aforementioned substrates with $n$-BuLi in THF at $-78^{\circ} \mathrm{C}$ and the trapping of the resulting lithiated species with electrophiles. We report, also, the enantioselective coupling reactions of 2-(but-2-ynyloxymethyl)benzothiazole with a number of carbon electrophiles in the presence of a chiral ligand to afford hydroxysubstituted propargylic ethers. Hydroxypropargylic compounds of this kind have been prepared by electrochemical propargylation of aldehydes and ketones, ${ }^{8}$ or by $\alpha$-chlorovinylation of aldehydes, followed by a based-induced elimination. ${ }^{9}$ The coupling reaction of $\alpha$ methoxybenzyl-lithium-chiral ligand complex with substituted propynals, ${ }^{10}$ or the addition of non-racemic propargylic mesylates to aldehydes $^{11}$ have been reported as providing enantioselective routes to hydroxypropargylic compounds.

\section{Results and Discussion}

The heteroarylalkyl propargyl ethers $\mathbf{1 - 5}$, prepared as reported, ${ }^{4}$ were treated with $n$-BuLi in THF at $-78^{\circ} \mathrm{C}$, in the presence of various electrophiles (Scheme 1). The resulting lithiated species coupled efficiently with the electrophile; the outcome of the coupling reaction depending upon the heterocyclic group linked to the ether. The incoming electrophile goes to the $\alpha$-carbon in the case of benzothiazolyl ethers, and to the $\alpha$ '-carbon atom with pyridyl-, thiazolyl-, and oxazolinyl ethers. Such a trend parallels the 1,2- and 2,3-Wittig rearrangements, which occur when the propargylic heteroaryl ethers are deprotonated in the absence of the external electrophile. Indeed, as anticipated in a previous paper, the deprotonation of 2-(but-2ynyloxymethyl)benzothiazole 1 with $n$-BuLi in $\mathrm{THF}$ at $-78^{\circ} \mathrm{C}$, followed by the addition of iodomethane, afforded the 2-[1-(but-2-ynyloxy)ethyl]benzothiazole $1 \mathbf{1 a}^{4}$ Thus proving that the carbanion generation takes place at the $\alpha$-carbon atom, immediately trapped by the $\mathrm{CH}_{3} \mathrm{I}$ (Table 1: Entry 1). 


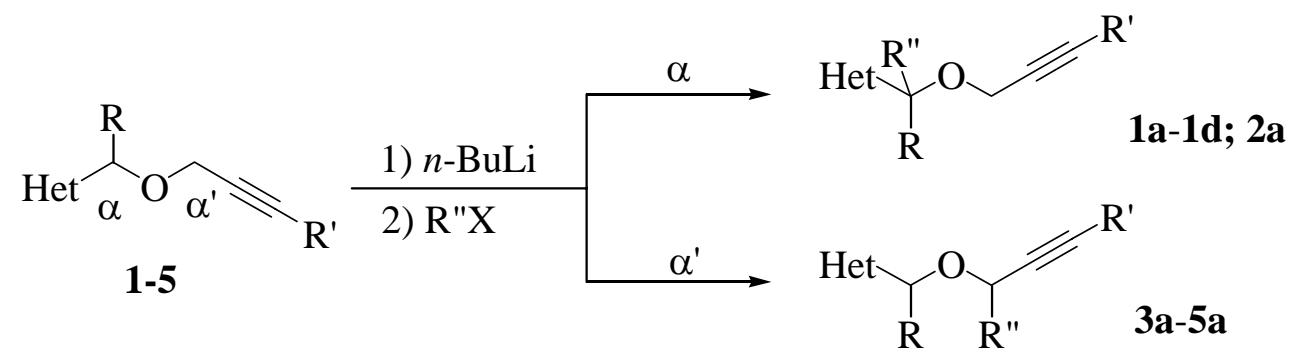

\begin{tabular}{|c|c|c|c|c|c|}
\hline Substrate & Het & $\mathrm{R}$ & $\mathrm{R}^{\prime}$ & R"X & Products \\
\hline 1 & & $\mathrm{H}$ & $\mathrm{CH}_{3}$ & $\mathrm{CH}_{3} \mathrm{I}$ & $1 a^{a}$ \\
\hline 1 & ", & $\mathrm{H}$ & $\mathrm{CH}_{3}$ & $\mathrm{Si}\left(\mathrm{CH}_{3}\right)_{3} \mathrm{Cl}$ & $1 \mathrm{~b}$ \\
\hline 1 & & $\mathrm{H}$ & $\mathrm{CH}_{3}$ & $\curvearrowright_{\mathrm{Br}}$ & 1c \\
\hline 1 & & $\mathrm{H}$ & $\mathrm{CH}_{3}$ & $\mathrm{Ph} \widehat{C l}$ & $1 d$ \\
\hline 2 & & $\mathrm{H}$ & $\mathrm{Ph}$ & $\mathrm{CH}_{3} \mathrm{I}$ & $2 a^{a}$ \\
\hline 3 & & $\mathrm{H}$ & $\mathrm{Ph}$ & $\mathrm{CH}_{3} \mathrm{I}$ & $3 a^{a}$ \\
\hline 4 & & $\mathrm{CH}_{3}$ & $\mathrm{Ph}$ & $\mathrm{CH}_{3} \mathrm{I}$ & $4 a$ \\
\hline 5 & & $\mathrm{CH}_{3}$ & $\mathrm{Ph}$ & $\mathrm{CH}_{3} \mathrm{I}$ & $5 a$ \\
\hline
\end{tabular}

${ }^{a}$ Compounds reported in a previous paper ${ }^{4}$ and listed in this Scheme only for comparison purposes.

Scheme 1. Coupling reactions of heteroarylalkyl propargyl ethers with alkyl halides.

Comparable results were obtained when the substrate $\mathbf{1}$ was deprotonated in the presence of different electrophiles, such as trimethylchlorosilane, allyl bromide, or benzyl chloride (entries 4 , 5 , and 6). The isolated reaction products were, again, coupling products at the $\alpha$-carbon atom. Similarly, treatment of 2 with $n$-BuLi in the presence of $\mathrm{CH}_{3} \mathrm{I}$ provided the $\alpha$-carbon- atommethylated compound $\mathbf{2 a}$ as the sole reaction product (80\% yield, entry 7 ). In contrast, treatment of 2-(3-phenylprop-2-ynyloxy-methyl)pyridine 3 with $n$-BuLi in the presence of $\mathrm{CH}_{3} \mathrm{I}$ afforded

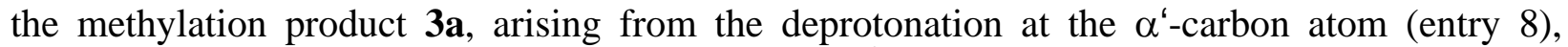
together with the [1,2]-Wittig rearrangement product. ${ }^{4}$ Similarly, deprotonation-methylation of $\mathbf{4}$ produced the methylation product $4 \mathbf{a}$, arising again from the deprotonation at the $\alpha$-carbon atom (55\% yield, entry 9), together with the [1,2]-Wittig rearrangement product. The deprotonationmethylation combination of 4,4-dimethyl-2-[1-(3-phenylprop-2-ynyloxy)ethyl]-4,5-dihydro-1,3oxazole 5 afforded compound $\mathbf{5 a}$ (60\% yield, entry 10 ) as the sole reaction product, arising from the deprotonation at the $\alpha^{\prime}$-carbon atom. 
Table 1. Coupling reactions of heteroarylalkyl propargyl ethers with electrophiles

\begin{tabular}{|c|c|c|c|c|c|c|c|}
\hline Entry & Substrate & Electrophile & Ligand & Solvent & $\begin{array}{l}\text { Products } \\
(\% \text { yield })^{\mathrm{a}}\end{array}$ & $e e^{\mathrm{b}}$ & {$[\alpha]_{D}^{22}$} \\
\hline 1 & 1 & $\mathrm{CH}_{3} \mathrm{I}$ & - & THF & $1 \mathrm{a}(95)^{\mathrm{c}}$ & - & - \\
\hline 2 & 1 & , & $(-)$-sparteine & $n$-hexane & $1 \mathrm{a}(40)$ & 14 & -12.5 \\
\hline 3 & 1 & , & , & toluene & 1a (90) & 60 & -53.2 \\
\hline 4 & 1 & $\mathrm{Si}\left(\mathrm{CH}_{3}\right)_{3} \mathrm{Cl}$ & - & THF & $1 \mathrm{~b}(78)$ & - & - \\
\hline 5 & 1 & & - & $”$ & 1c $(60)$ & - & - \\
\hline 6 & 1 & $\mathrm{Ph} \widehat{\mathrm{Cl}}$ & - & , & $1 d(50)$ & - & - \\
\hline 7 & 2 & $\mathrm{CH}_{3} \mathrm{I}$ & - & , & $2 a(80)^{c}$ & - & - \\
\hline 8 & 3 & $”$ & - & , & 3a $(30)^{c}$ & - & - \\
\hline 9 & 4 & , & - & ” & 4a (55) & - & - \\
\hline 10 & 5 & ” & - & ” & 5a (60) & - & - \\
\hline 11 & 1 & $\mathrm{Me}_{2} \mathrm{CO}$ & - & , & 1e (75) & - & - \\
\hline 12 & 1 & » & (-)-sparteine & $n$-hexane & 1e (40) & 14 & +15.3 \\
\hline 13 & 1 & , & » & toluene & 1e (44) & 64 & +69.6 \\
\hline 14 & 1 & $\mathrm{Et}_{2} \mathrm{CO}$ & - & THF & $1 \mathrm{f}(70)$ & - & - \\
\hline 15 & 1 & $”$ & (-)-sparteine & $n$-hexane & $1 \mathrm{f}(30)$ & 20 & +24.2 \\
\hline 16 & 1 & » & ” & toluene & $1 \mathrm{f}(60)$ & 50 & +60.9 \\
\hline 17 & 1 & $n-\mathrm{Pr}_{2} \mathrm{CO}$ & - & THF & $\lg (79)$ & - & - \\
\hline 18 & 1 & $”$ & (-)-sparteine & $n$-hexane & 1g (35) & 16 & +18.1 \\
\hline 19 & 1 & & , & toluene & $\lg (57)$ & 60 & +65.4 \\
\hline 20 & 1 & & - & THF & 1h (81) & - & - \\
\hline 21 & 1 & , & (-)-sparteine & $n$-hexane & 1h (56) & 50 & +15.5 \\
\hline 22 & 1 & & ” & toluene & 1h (59) & 56 & +17.3 \\
\hline 23 & 1 & & - & THF & $1 \mathrm{i}(90)$ & - & - \\
\hline 24 & 1 & & - & THF & $11(71)$ & - & - \\
\hline 25 & 1 & „ & (-)-sparteine & $n$-hexane & $1 \mathrm{l}(70)$ & 50 & +11.1 \\
\hline 26 & 1 &, & „ & toluene & $1 \mathrm{l}(96)$ & 60 & +13.0 \\
\hline
\end{tabular}

${ }^{\mathrm{a}}$ Isolated yields. ${ }^{\mathrm{b}} e e=$ enantiomeric enrichment. ${ }^{\mathrm{c}}$ Data reported in a previous paper ${ }^{4}$ and listed in this Table only for comparison purposes.

The consideration that the deprotonation-alkylation sequence of the above propargylic ethers provides products with new stereogenic centres prompted us to investigate a possible asymmetric induction by using an external chiral ligand. The coupling reaction of the substrate $\mathbf{1}$ with iodomethane was then carried out in the presence of (-)-sparteine as the external chiral ligand, in 
$n$-hexane and toluene (entries 2 and 3). A reasonable level of enantioselection was observed, and this seemed to be remarkably dependent upon the solvent used. In $n$-hexane, low enantioselectivity ( $e e=14$, entry 2 ) was observed; in toluene the methylated product 1a was isolated with a good enantiomeric enrichment ( $e e=60$; entry 3 ), according to the results reported for asymmetric [2,3]-Wittig rearrangements of crotyl furfuryl ethers. ${ }^{12}$ Encouraged by these findings, we performed several coupling reactions of substrate 1 with various symmetric ketones, obtaining hydroxypropargylic ethers as the only reaction products (Scheme 2).
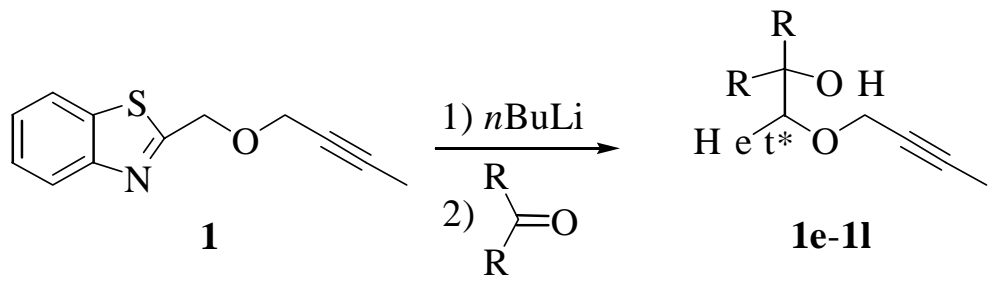

\begin{tabular}{lll}
\hline 1e & $\mathrm{R}, \mathrm{R}=$ & $\mathrm{CH}_{3}$ \\
1f & $\mathrm{R}, \mathrm{R}=$ & $\mathrm{CH}_{2} \mathrm{CH}_{3}$ \\
1g & $\mathrm{R}, \mathrm{R}=$
\end{tabular}

Scheme 2. Coupling reaction of 2-(but-2-ynyloxymethyl)benzothiazole, $\mathbf{1}$, with symmetrical ketones.

In order to check the asymmetric induction in more detail, each reaction was performed in three different solvents: THF, $n$-hexane and toluene, in the presence of (-)-sparteine. The presence of the external chiral ligand usually lowered the yield of the coupling product. No enantioselection was observed in THF, and the lack of stereoselection could be ascribed to the THF's co-ordinating power, which probably prevents the generation of chiral co-ordinated intermediate involving the lithiated species and (-)-sparteine. In $n$-hexane, and especially in toluene, the (-)-sparteine allowed the formation of a chiral co-ordinated anion leading, by coupling with the corresponding ketone, to hydroxypropargylic ethers with remarkable enantiomeric enrichments (Table 1). The enantiomeric enrichments were measured, for almost all the reactions, by HPLC analyses (more details are given in the Experimental Section). The 
enantiomeric enrichment of $\mathbf{1 g}$ and $\mathbf{1 l}$ (entries 18-19, 25-26) was measured by ${ }^{1} \mathrm{H}$ NMR analyses, calculating the integral's ratio of the two different broad signals given by the enantiomeric protons ( $\delta=5.30$ and 5.22 for $\mathbf{1 g}, \delta=6.50$ and 5.60 for $\mathbf{1 l}$ ) distinguished by adding $\mathrm{Eu}(\mathrm{tfc})_{3}$ as chiral NMR shift reagent. When cyclohexanone was used as the electrophile (entry 23) neither HPLC, nor the ${ }^{1} \mathrm{H}$ NMR technique allowed us to measure any enantiomeric enrichment of $\mathbf{1 i}$.

In conclusion, we have shown that heteroarylalkyl propargyl ethers, deprotonated at the $\alpha$ carbon atom or at the $\alpha^{4}$-carbon atom, depending on the stabilizing group of the carbanionic center, undergo a coupling reaction with a number of different electrophiles. Using this protocol, more complicated organic structures can be synthesized, such as compounds containing alkyl- or alcoholic functions. The carbanion complexation by an external chiral ligand leads to enantiomerically enriched mixtures $(e e=64)$. The option of freeing the acyl groups masked by the heterocycles (benzothiazole, thiazole, oxazoline) and the presence in their framework of various functions, makes them good intermediates for polyfunctional compounds such as heteroaryl hydroxy aldehydes which are of synthetic interest.

\section{Experimental Section}

General Procedures. $n$-BuLi was a commercial solution in hexanes (Aldrich) and was titrated with N-pivaloyl-o-toluidine prior to use. ${ }^{13}$ THF, $n$-hexane, toluene, (-)-sparteine, iodomethane, chlorotrimethylsilane, alkyl chlorides (allyl bromide, benzyl chloride), ketones (acetone, 3pentanone, 4-heptanone, cyclopentanone, cyclohexanone, 2-adamantanone) were of commercial grade (Aldrich), as were europium D-3-trifluoroacetylcamphorate [Eu(tfc) 3 , and were used without further purification. Petroleum ether refers to the $40-60^{\circ} \mathrm{C}$ boiling fraction. The ${ }^{1} \mathrm{H}$ - and ${ }^{13} \mathrm{C}$ - NMR spectra were recorded with a Bruker AC 200 apparatus $\left(200 \mathrm{MHz}\right.$ for ${ }^{1} \mathrm{H}$, and 50.3 $\mathrm{MHz}$ for ${ }^{13} \mathrm{C}$ ) with $\mathrm{CDCl}_{3}$ as solvent and TMS as internal standard (chemical shifts in ppm: $\delta_{\mathrm{H}}=$ 7.24 for ${ }^{1} \mathrm{H}$ - spectra; $\delta_{\mathrm{H}}=77.0$ for ${ }^{13} \mathrm{C}$ - spectra). The IR spectra were recorded with a Perkin Elmer spectrometer Model 283. GC-MS analyses were performed with a Hewlett-Packard HP5890 series II gas chromatograph (5\% phenylmethylsiloxane capillary column, $30 \mathrm{~m}, 0.25 \mathrm{~mm}$ i.d.), equipped with an HP 5971 mass-selective detector operating at $70 \mathrm{eV}$ (EI). A Jasco P-1020 polarimeter was used for polarimetric measurements. HPLC analyses were performed with a Hewlett-Packard system, 1100 series, containing a binary pump G1312A, a UV-variablewavelength detector G1314A (detection at $254 \mathrm{~nm}$ ) and equipped with a chiral column Chiracel OB-H. Eluent mixtures used for HPLC were $n$-hexane/ethanol or $n$-hexane/2-propanol. Melting points are uncorrected. TLC was performed on Merck silica gel plates with F-254 indicator; viewing was by UV light $(254 \mathrm{~nm})$. Column chromatography was performed on silica gel (63-200 $\mu \mathrm{m})$, flash column chromatography was performed on silica gel $(40-63 \mu \mathrm{m})$ with petroleum ether/diethyl ether $\left(\mathrm{Et}_{2} \mathrm{O}\right)$ mixtures as eluents. All reactions involving air-sensitive 
reagents were performed under nitrogen in oven-dried glassware using syringe/septum cap techniques.

\section{General procedure for the coupling reactions of heteroarylalkyl propargyl ethers with alkyl halides}

1a and 3a were prepared as reported. ${ }^{4}$ The synthesis of the compound 1a was performed also in the presence of $(-)$-sparteine $(2 \mathrm{mmol})$ in $n$-hexane and toluene as solvent, following the same reported procedure. ${ }^{4}$ Compounds $\mathbf{1 b}, \mathbf{2 a}, \mathbf{4 a}$, and $\mathbf{5 a}$ were prepared by stirring the corresponding pure product $\mathbf{1}, \mathbf{2}, \mathbf{4}$ or $\mathbf{5}(1 \mathrm{mmol})$ at $-78^{\circ} \mathrm{C}$ in $15 \mathrm{~mL}$ of THF, adding dropwise, under $\mathrm{N}_{2}$, first the corresponding alkyl halide $(2 \mathrm{mmol})$ and then a solution of $n$-BuLi in hexanes (2.5 M, 0.5 $\mathrm{mL}, 1.25 \mathrm{mmol}$ ). After $30 \mathrm{~min}$, the mixture was allowed to warm slowly to room temperature (over ca. $1 \mathrm{~h}$ ), then quenched with $40 \mathrm{~mL}$ of a saturated aqueous $\mathrm{NH}_{4} \mathrm{Cl}$ solution and extracted with $\mathrm{Et}_{2} \mathrm{O}(3 \times 20 \mathrm{~mL})$. The combined organic layers were dried $\left(\mathrm{Na}_{2} \mathrm{SO}_{4}\right)$ and concentrated in vacuo. The crude products $\mathbf{1 b}$ and $\mathbf{5 a}$ were purified by flash column chromatography (silica gel: 40-63 $\mu \mathrm{m}$; petroleum ether for $\mathbf{1 b}$, petroleum ether/Et $\mathrm{t}_{2} \mathrm{O} 1: 1$ for $\mathbf{5 a}$ ) to afford the pure heteroarylalkyl propargyl ethers (oils); yield, 78\% and 60\%, respectively. The crude products 2a and 4a were purified by column chromatography (silica gel: 63-200 $\mu \mathrm{m}$; petroleum ether/ $\mathrm{Et}_{2} \mathrm{O}$ 1:1 for 2a and 8:2 for $\mathbf{4 a}$ ) to afford the pure heteroarylalkyl propargyl ethers (2a solid, 4a oil); yield, $80 \%$ and 55\%, respectively. The compound 2a can be synthesized alternatively by stirring a solution of 1-(benzothiazol-2-yl)ethanol and (3-chloroprop-2-ynyl)benzene in acetone/sodium hydroxide. ${ }^{4}$ Compounds $\mathbf{1 c}$, and $\mathbf{1 d}$ were prepared by stirring the pure substrate $\mathbf{1}$ (1 mmol) at $78^{\circ} \mathrm{C}$ in $15 \mathrm{~mL}$ of THF, adding dropwise, under $\mathrm{N}_{2}$, first a solution of $n$-BuLi in hexanes (2.5 $M$, $0.5 \mathrm{~mL}, 1.25 \mathrm{mmol})$ and then the corresponding alkyl halide $(2 \mathrm{mmol})$. The mixtures were treated as reported above for the compound $\mathbf{1 b}$; the crude products were purified by column chromatography (silica gel $63-200 \mu \mathrm{m}$; petroleum ether/Et $\mathrm{t}_{2} \mathrm{O}, 1: 1$ ) to afford the pure heteroarylalkyl propargyl ethers 1c and 1d, (oils); yield, 60\% and 50\%, respectively.

2-[1-(But-2-ynyloxy)ethyl]benzothiazole (1a). In n-hexane; yield, $92 \mathrm{mg}$ (40\%), oil. HPLC: flow $0.3 \mathrm{ml} / \mathrm{min}$., eluent, ethanol $/ n$-hexane, 4:96, ee $=14$. $[\alpha]_{\mathrm{D}}^{22}=-12.5$. In toluene; yield, 208 mg (90\%), oil. HPLC: flow $0.3 \mathrm{ml} / \mathrm{min}$., eluent, ethanol $/ n$-hexane, 4:96, ee $=60 .[\alpha]_{\mathrm{D}}{ }^{22}=-53.2$.

2-(But-2-ynyloxytrimethylsilanylmethyl)benzothiazole (1b). Yield, $225 \mathrm{mg}$ (78\%), oil. ${ }^{1} \mathrm{H}$ NMR (200 MHz, $\mathrm{CDCl}_{3}$ ): $\delta=0.13$ (s, 9H), 1.85 (t, $\left.J=2.3 \mathrm{~Hz}, 3 \mathrm{H}\right), 3.71-3.77$ (m, 2H), 6.9 (s, $1 \mathrm{H}), 7.23-7.60$ (m, 2H), 7.91 (dd, $J=1.3,8.0 \mathrm{~Hz}, 1 \mathrm{H}), 8.05$ (d, $J=7.7 \mathrm{~Hz}, 1 \mathrm{H}) .{ }^{13} \mathrm{C}$ NMR $(50.3$ $\left.\mathrm{MHz}, \mathrm{CDCl}_{3}\right): \delta=1.8,3.5,59.2,68.0,73.9,82.8,121.7,122.9,125.0,126.0,134.9,152.8$, 175.0. GC-MS (EI, $70 \mathrm{eV}) \mathrm{m} / \mathrm{z}(\%): 289\left(\mathrm{M}^{+}, 0\right), 216$ (10), 202 (28), 149 (100). IR $\left(\mathrm{CHCl}_{3}\right): v$ = 3060, 2920, 2860, 2220, 1520, 1440, 1350, 1100, 760, $730 \mathrm{~cm}^{-1}$.

4-Methyl-2-[1-(1-methyl-3-phenylprop-2-ynyloxy)ethyl]thiazole (4a). Yield, 149 mg (55\%), oil. ${ }^{1} \mathrm{H}$ NMR (200 MHz, $\mathrm{CDCl}_{3}$ ): $\delta=0.90$ (d, $\left.J=6.7 \mathrm{~Hz}, 3 \mathrm{H}\right), 1.65$ (d, $\left.J=6.7 \mathrm{~Hz}, 3 \mathrm{H}\right), 2.44$ (s, 3H), 4.30 (q, $J=6.7 \mathrm{~Hz}, 1 \mathrm{H}), 5.0$ (q, $J=6.7 \mathrm{~Hz}, 1 \mathrm{H}), 6.8(\mathrm{~s}, 1 \mathrm{H}), 7.26-7.70(\mathrm{~m}, 5 \mathrm{H}) .{ }^{13} \mathrm{C}$ NMR (50.3 MHz, $\left.\mathrm{CDCl}_{3}\right): \delta=16.3,21.5,22.8,57.3,74.0,74.5,83.0,113.1,128.0,128.5,131.5$, 
133.5, 152.4, 173.2 GC-MS (EI, 70 eV) m/z (\%): 271 (M+, 6), 256 (20), 126 (90), 129 (100), 77 (25). IR (film): $v=3055$ (br.), 2990, 2910, 2850, 2220, 1530, 1440, 1300, $1100 \mathrm{~cm}^{-1}$.

4,4-Dimethyl-2-[1-(1-methyl-3-phenylprop-2-ynyloxy)ethyl]-4,5-dihydro-1,3-oxazole (5a). Yield, $163 \mathrm{mg}$ (60\%), oil. ${ }^{1} \mathrm{H}$ NMR (200 MHz, $\mathrm{CDCl}_{3}$ ), $\delta=1.30$ (d, $\left.J=6.6 \mathrm{~Hz}, 3 \mathrm{H}\right), 1.34$ (s, $6 \mathrm{H}), 1.45$ (d, $J=6.6 \mathrm{~Hz}, 3 \mathrm{H}), 3.90$ (s, 2H), 4.18 (q, $J=6.6 \mathrm{~Hz}, 1 \mathrm{H}), 4.45$ (q, $J=6.6 \mathrm{~Hz}, 1 \mathrm{H}$ ), 7.20-7.50 (m, 5H). ${ }^{13} \mathrm{C}$ NMR (50.3 MHz, $\left.\mathrm{CDCl}_{3}\right), \delta=18.7,21.0,28.2,57.1,67.1,69.9,79.4$, 84.8, 86.5, 122.5, 128.2, 128.4, 131.8, 165.0. GC-MS (EI, $70 \mathrm{eV}) ; \mathrm{m} / \mathrm{z}(\%): 271\left(\mathrm{M}^{+}, 1\right), 270$ (1), 145 (45), 128 (53), 115 (24), 74 (100). IR (film): $v=3060,2980,2850,2225,1660,1100,750$, $690 \mathrm{~cm}^{-1}$.

2-(1-But-2-ynyloxybut-3-enyl)benzothiazole (1c). Yield, $154 \mathrm{mg}$ (60\%), oil. ${ }^{1} \mathrm{H}$ NMR (200 $\mathrm{MHz}_{\mathrm{CDCl}}$ ), $\delta=1.83(\mathrm{t}, J=2.0 \mathrm{~Hz}, 3 \mathrm{H}), 2.76(\mathrm{t}, J=6.6 \mathrm{~Hz}, 2 \mathrm{H}), 4.15$ (dq, $J=2.3,15.0 \mathrm{~Hz}$, $1 \mathrm{H}), 4.28$ (dq, $J=2.3,15.0 \mathrm{~Hz}, 1 \mathrm{H}), 5.02-5.20$ (m, 3H), 5.81-5.95 (m, 1H), 7.35-7.52 (m, 2H), 7.91 (d, $J=7.7 \mathrm{~Hz}, 1 \mathrm{H}), 8.00$ (d, $J=8.0 \mathrm{~Hz}, 1 \mathrm{H}) .{ }^{13} \mathrm{C} \mathrm{NMR}\left(50.3 \mathrm{MHz}, \mathrm{CDCl}_{3}\right): \delta=3.6,40.8$, 57.9, 77.2, 78.1, 83.4, 118.2, 121.8, 123.0, 125.1, 125.9, 132.8, 134.9, 153.7, 175.1. GC-MS (EI, $70 \mathrm{eV}) ; \mathrm{m} / \mathrm{z}$ (\%), $257\left(\mathrm{M}^{+}, 2\right), 242$ (5), 216 (80), 204 (32), 189 (44), 164 (100). IR (film), v = 3060, 2920, 2850, 2220, 1520, 1450, 1320, 1180, 1020, 920, 760, $730 \mathrm{~cm}^{-1}$.

2-(1-But-2-ynyloxy-2-phenylethyl)benzothiazole (1d). Yield, $153 \mathrm{mg}$ (50\%), oil. ${ }^{1} \mathrm{H}$ NMR $\left(200 \mathrm{MHz}, \mathrm{CDCl}_{3}\right), \delta=1.56(\mathrm{t}, J=2.5 \mathrm{~Hz}, 3 \mathrm{H}), 3.89$ (dq, $\left.J=2.5,20.0 \mathrm{~Hz}, 1 \mathrm{H}\right), 4.05$ (dq, $J=$ 2.5, 20.0 Hz, 1H), 5.08-5.27 (m, 2H), 6.50 (t, $6.8 \mathrm{~Hz}, 1 \mathrm{H}), 6.80-7.50$ (m, 7H), 7.90 (dd, $J=0.8$, $7.5 \mathrm{~Hz}, 1 \mathrm{H}), 7.99$ (dd, $J=0.8,7.5 \mathrm{~Hz}, 1 \mathrm{H}) .{ }^{13} \mathrm{C} \mathrm{NMR}\left(50.3 \mathrm{MHz}, \mathrm{CDCl}_{3}\right), \delta=3.5,39.2,58.9$, 69.7, 74.0, 85.2, 121.5, 122.1, 125.6, 126.8, 127.7, 128.2, 129.2, 130.0, 135.2, 152.1, 174.9. GCMS (EI, $70 \mathrm{eV}) ; \mathrm{m} / \mathrm{z}$ (\%), $307\left(\mathrm{M}^{+}, 6\right), 254$ (12), 216 (100), 164 (60), 91 (35). IR (film): v $=3060,3020,2920,2850,2215,1610,1580,1490,1080,1070,750,700 \mathrm{~cm}^{-1}$.

General procedure for the coupling reactions of 2-(but-2-ynyloxymethyl)benzothiazole 1 with symmetrical ketones

1e-1l were prepared by stirring the substrate 1 (1 mmol) in $15 \mathrm{~mL}$ of $\mathrm{THF}$ at $-78^{\circ} \mathrm{C}[(-)$ sparteine ( $2 \mathrm{mmol}$ ) was used with $n$-hexane or toluene as solvent], adding dropwise, under $\mathrm{N}_{2}$, first a solution of $n$-BuLi in hexanes $(2.5 \mathrm{M}, 0.5 \mathrm{~mL}, 1.25 \mathrm{mmol})$ and after $10 \mathrm{~min}$. the corresponding ketone ( $2 \mathrm{mmol}$ ). After $30 \mathrm{~min}$., the mixture was slowly allowed to warm to room temperature (over ca. $1 \mathrm{~h}$ ), then quenched with $40 \mathrm{~mL}$ of a saturated aqueous $\mathrm{NH}_{4} \mathrm{Cl}$ solution and extracted with $\mathrm{Et}_{2} \mathrm{O}(3 \mathrm{x} 20 \mathrm{~mL})$. The combined organic layers were dried $\left(\mathrm{Na}_{2} \mathrm{SO}_{4}\right)$ and concentrated in vacuo. The crude products $\mathbf{1 e}-\mathbf{1 l}$ were purified by column chromatography (silica gel 63-200 $\mu \mathrm{m}$; petroleum ether/ $\mathrm{Et}_{2} \mathrm{O}$, 1:1 for 1e, 8:2 for $\mathbf{1 f}$ and $\mathbf{1 g}$, 7:3 for 1h-1l) to afford the pure heteroaryl hydroxypropargylic ethers (1e-1i oils, $\mathbf{1 l}$ solid); yield, 70-90\% in THF.

2-(Benzothiazol-2-yl-1-but-2-ynyloxymethyl)propan-2-ol (1e). In THF; yield, 206 mg (75\%), oil. ${ }^{1} \mathrm{H}$ NMR (200 MHz, $\mathrm{CDCl}_{3}$ ), $\delta=1.29$ (s, 6H), 1.83 (t, $J=2.3 \mathrm{~Hz}, 3 \mathrm{H}$ ), 2.90 (br. s, 1H, exchanges with $\mathrm{D}_{2} \mathrm{O}$ ), 4.20 (dq, $\left.J=2.3,15.2 \mathrm{~Hz}, 1 \mathrm{H}\right), 4.40$ (dq, $\left.J=2.3,15.2 \mathrm{~Hz}, 1 \mathrm{H}\right), 4.80$ (s, 1H), 7.35-7.54 (m, 2H), 7.90 (d, $J=7.9 \mathrm{~Hz}, 1 \mathrm{H}), 8.03$ (d, $J=8.0 \mathrm{~Hz}, 1 \mathrm{H}) .{ }^{13} \mathrm{C} \mathrm{NMR}(50.3 \mathrm{MHz}$, 
$\left.\mathrm{CDCl}_{3}\right), \delta=3.5,25.5,25.7,59.0,72.7,74.1,83.9,84.3,121.7,123.0,125.2,126.1,132.2,153.0$, 172.1. GC-MS (EI, $70 \mathrm{eV}$ ); m/z (\%), 275 (M+ 0), 217 (7), 164 (100), 136 (15), 109 (7). IR (film), $v=3420$ (br.), 3060, 2970, 2910, 2850, 2220, 1500, 1440, 1370, 1310, 1160, 1070, 1020, 760, $730 \mathrm{~cm}^{-1}$. In $n$-hexane; yield, $110 \mathrm{mg}$ (40\%), oil. HPLC; flow $0.5 \mathrm{ml} / \mathrm{min}$.; eluent, 2propanol $/ n$-hexane, 5:95, $e e=14 .[\alpha]_{\mathrm{D}}^{22}=+15.3$. In toluene; yield, $121 \mathrm{mg}(44 \%)$, oil. HPLC: flow $0.5 \mathrm{ml} / \mathrm{min}$., eluent, 2-propanol $/ n$-hexane, 5:95, ee $=64 .[\alpha]_{\mathrm{D}}^{22}=+69.6$.

3-(Benzothiazol-2-ylbut-2-ynyloxymethyl)pentan-3-ol (1f). In THF; yield, 212 mg (70\%), oil. ${ }^{1} \mathrm{H}$ NMR $\left(200 \mathrm{MHz}, \mathrm{CDCl}_{3}\right), \delta=0.92(\mathrm{t}, J=7.0 \mathrm{~Hz}, 3 \mathrm{H}), 0.95(\mathrm{t}, J=7.0 \mathrm{~Hz}, 3 \mathrm{H}), 1.25-1.70(\mathrm{~m}$, $4 \mathrm{H}$ ), 1.82 (t, $J=2.3 \mathrm{~Hz}, 3 \mathrm{H}$ ), 2.40 (br. s, $1 \mathrm{H}$, exchanges with $\mathrm{D}_{2} \mathrm{O}$ ), 4.08 (dq, $J=2.3,15.4 \mathrm{~Hz}$, $1 \mathrm{H}), 4.31$ (dq, $J=2.3,15.4 \mathrm{~Hz}, 1 \mathrm{H}), 4.94(\mathrm{~s}, 1 \mathrm{H}), 7.35-7.50$ (m, 2H), 7.90 (d, $J=7.3 \mathrm{~Hz}, 1 \mathrm{H}$ ), $8.02(\mathrm{~d}, J=7.5 \mathrm{~Hz}, 1 \mathrm{H}) .{ }^{13} \mathrm{C}$ NMR $\left(50.3 \mathrm{MHz}, \mathrm{CDCl}_{3}\right), \delta=3.6,7.1,7.8,26.5,27.6,58.2,74.3$, 76.5, 81.3, 83.6, 121.7, 123.0, 125.2, 125.9, 135.3, 152.5, 171.3. GC-MS (EI, $70 \mathrm{eV}$ ); m/z (\%), 303 ( $\mathrm{M}^{+}, 0$ ), 274 (2), 217 (8), 164 (100), 136 (9). IR (film); v = 3430 (br.), 3060, 2960, 2930, 2220, 1500, 1450, 1430, 1315, 1140, 1070, 1060, 760, $730 \mathrm{~cm}^{-1}$. In $n$-hexane; yield, $91 \mathrm{mg}$ (30\%), oil. HPLC, flow $0.2 \mathrm{ml} / \mathrm{min}$., eluent; ethanol $/ n$-hexane, 1:99, ee $=20 .[\alpha]_{\mathrm{D}}{ }^{22}=+24.2$. In toluene; yield, $182 \mathrm{mg}(60 \%)$, oil. HPLC: flow $0.2 \mathrm{ml} / \mathrm{min}$., eluent, ethanol $/ n$-hexane, 1:99, ee = 50. $[\alpha]_{\mathrm{D}}^{22}=+60.9$.

4-(Benzothiazol-2-ylbut-2-ynyloxymethyl)heptan-4-ol (1g). Yield, $262 \mathrm{mg}(79 \%)$, oil. ${ }^{1} \mathrm{H}$ NMR (200 MHz, CDCl 3 ), $\delta=0.80-0.95$ (m, 6H), 1.36-1.80 (m, 8H), 1.81 (t, $J=2.3 \mathrm{~Hz}, 3 \mathrm{H}$ ), 2.40 (br. s, $1 \mathrm{H}$, exchanges with $\mathrm{D}_{2} \mathrm{O}$ ), 4.08 (dq, $\left.J=2.3,15.4 \mathrm{~Hz}, 1 \mathrm{H}\right), 4.31$ (dq, $J=2.3,15.4 \mathrm{~Hz}$, 1H), 4.94 (s, $1 \mathrm{H}), 7.35-7.50(\mathrm{~m}, 2 \mathrm{H}), 7.90$ (d, $J=7.3 \mathrm{~Hz}, 1 \mathrm{H}), 8.02(\mathrm{~d}, J=7.5 \mathrm{~Hz}, 1 \mathrm{H}) .{ }^{13} \mathrm{C}$ NMR (50.3 MHz, $\mathrm{CDCl}_{3}$ ), $\delta=3.5,14.5,14.6,16.2,16.8,36.8,38.1,58.2,74.3,76.2,81.9,83.5$, 121.7, 123.0, 125.1, 125.8, 135.3, 152.5, 171.4. GC-MS (EI, $70 \mathrm{eV}) ; \mathrm{m} / \mathrm{z}(\%), 331$ (M+1 0$), 217$ (16), 164 (100), 149 (50), 136 (22). IR (film); $v=3430$ (br.), 3060, 2970, 2860, 2225, 1500, 1450, 1430, 1315, 1140, 1070, 1000, 760, $730 \mathrm{~cm}^{-1}$. In $n$-hexane; yield, $116 \mathrm{mg}$ (35\%), oil. ${ }^{1} \mathrm{H}$ NMR (200 MHz), adding Eu(tfc) ${ }_{3} \delta=5.30$ and 5.22 broad signals (enantiomeric protons), $e e=$ 16. $[\alpha]_{\mathrm{D}}{ }^{22}=+18.1$. In toluene; yield, $189 \mathrm{mg}(57 \%)$, oil. ${ }^{1} \mathrm{H} \mathrm{NMR}(200 \mathrm{MHz})$, adding $\mathrm{Eu}(\mathrm{tfc})_{3} \delta$ $=5.30$ and 5.22 broad signals (enantiomeric protons), $e e=60 .[\alpha]_{\mathrm{D}}^{22}=+65.4$.

1-(Benzothiazol-2-ylbut-2-ynyloxymethyl)cyclopentanol (1h). Yield, $244 \mathrm{mg}$ (81\%), oil. ${ }^{1} \mathrm{H}$ NMR (200 MHz, CDCl $), \delta=1.40-1.90(\mathrm{~m}, 8 \mathrm{H}), 1.82(\mathrm{t}, J=2.3 \mathrm{~Hz}, 3 \mathrm{H}), 2.65$ (br. s, $1 \mathrm{H}$, exchanges with $\mathrm{D}_{2} \mathrm{O}$ ), 4.15 (dq, $\left.J=2.3,12.0 \mathrm{~Hz}, 1 \mathrm{H}\right), 4.34$ (dq, $\left.J=2.3,12.0 \mathrm{~Hz}, 1 \mathrm{H}\right), 4.90$ (s, $1 \mathrm{H}), 7.38-7.52(\mathrm{~m}, 2 \mathrm{H}), 7.91$ (d, $J=7.4 \mathrm{~Hz}, 1 \mathrm{H}), 8.03$ (d, $J=7.8 \mathrm{~Hz}, 1 \mathrm{H}) .{ }^{13} \mathrm{C}$ NMR $(50.3 \mathrm{MHz}$, $\left.\mathrm{CDCl}_{3}\right), \delta=3.5,24.0,24.2,36.0,37.7,58.5,74.2,82.8,83.6,83.7,121.7,123.1,125.1,125.9$, 135.2, 152.7, 171.5. GC-MS (EI, $70 \mathrm{eV}) ; \mathrm{m} / \mathrm{z}$ (\%), $301\left(\mathrm{M}^{+}, 0\right), 248$ (2), 217 (6), 164 (100), 136 (10), 109 (6). IR (film); $v=3400$ (br.), 3060, 2960, 2920, 2850, 2220, 1500, 1430, 1315, 1080, 1020, 760, $730 \mathrm{~cm}^{-1}$. In $n$-hexane, yield, $169 \mathrm{mg}$ (56\%), oil. HPLC; flow $0.3 \mathrm{ml} / \mathrm{min}$., eluent, ethanol $/ n$-hexane, 4:96, ee $=50$. $[\alpha]_{\mathrm{D}}^{22}=+15.5$. In toluene, yield, $178 \mathrm{mg}(59 \%)$, oil. HPLC, flow $0.3 \mathrm{ml} / \mathrm{min}$., eluent, ethanol $/ n$-hexane, 4:96, $e e=56 .[\alpha]_{\mathrm{D}}^{22}=+17.3$.

1-(Benzothiazol-2-ylbut-2-ynyloxymethyl)cyclohexanol (1i). Yield, $236 \mathrm{mg}(90 \%)$, oil. ${ }^{1} \mathrm{H}$ NMR (200 MHz, CDCl 3 ), $\delta=1.20-1.70(\mathrm{~m}, 10 \mathrm{H}), 1.80(\mathrm{t}, J=2.3 \mathrm{~Hz}, 3 \mathrm{H}), 2.78$ (br. s, $1 \mathrm{H}$, exchanges with $\mathrm{D}_{2} \mathrm{O}$ ), $4.11(\mathrm{dq}, J=2.3,15.4 \mathrm{~Hz}, 1 \mathrm{H}), 4.35(\mathrm{dq}, J=2.3,15.4 \mathrm{~Hz}, 1 \mathrm{H}), 4.80(\mathrm{~s}$, 1H), 7.32-7.50 (m, 2H), 7.86 (d, $J=7.9 \mathrm{~Hz}, 1 \mathrm{H}), 7.99$ (d, $J=8.0 \mathrm{~Hz}, 1 \mathrm{H}) .{ }^{13} \mathrm{C}$ NMR $(50.3 \mathrm{MHz}$, 
$\left.\mathrm{CDCl}_{3}\right), \delta=3.6,21.3,21.5,25.6,33.3,33.9,58.6,73.3,74.2,83.6,83.8,121.6,123.0,125.1$, 125.8, 135.2, 153.2, 171.2. GC-MS (EI, $70 \mathrm{eV}) ; \mathrm{m} / \mathrm{z}(\%): 262$ (M $\left.{ }^{+}, 0\right), 217$ (10), 164 (100), 149 (3), 136 (8). IR (film); $v=3420$ (br.), 3060, 2930, 2850, 2230, 1500, 1440, 1315, 1080, 1050, $760,730 \mathrm{~cm}^{-1}$.

2-(Benzothiazol-2-ylbut-2-ynyloxymethyl)adamantan-2-ol (11). Yield, $261 \mathrm{mg}$ (71\%), m.p. 95-96 ${ }^{\circ} \mathrm{C}$ (petroleum ether). ${ }^{1} \mathrm{H}$ NMR $\left(200 \mathrm{MHz}, \mathrm{CDCl}_{3}\right), \delta=0.90-2.30$ (m, 17H), 2.55 (br. s, $1 \mathrm{H}$, exchanges with $\mathrm{D}_{2} \mathrm{O}$ ), 3.98 (dq, $J=2.2,15.5 \mathrm{~Hz}, 1 \mathrm{H}$ ), 4.21 (dq, $J=2.2,15.5 \mathrm{~Hz}, 1 \mathrm{H}$ ), 5.52 (s, 1H), 7.34-7.46 (m, 2H), 7.86 (d, $J=7.8 \mathrm{~Hz}, 1 \mathrm{H}), 8.01(\mathrm{~d}, J=8.1 \mathrm{~Hz}, 1 \mathrm{H}) .{ }^{13} \mathrm{C}$ NMR $(50.3$ $\left.\mathrm{MHz}, \mathrm{CDCl}_{3}\right), \delta=3.6,23.3,24.3,26.9,27.2,27.3,32.9,35.5,36.9,38.0,74.7,75.0,76.5,79.1$, 83.2, 121.7, 123.1, 125.2, 125.7, 135.8, 152.1, 169.4. GC-MS (EI, $70 \mathrm{eV}) ; \mathrm{m} / \mathrm{z}(\%), 367\left(\mathrm{M}^{+}, 1\right)$, 217 (11), 164 (100), 151 (6), 136 (6). IR (film), $v=3400$ (br.), 3060, 2910, 2850, 2225, 1600, 1450, 1350, 1315, 1140, 1060, 1010, 995, 760, $730 \mathrm{~cm}^{-1}$. In $n$-hexane, yield, $257 \mathrm{mg}$ (70\%), solid. ${ }^{1} \mathrm{H}$ NMR (200 $\mathrm{MHz}, \mathrm{CDCl}_{3}$ ), adding $\mathrm{Eu}(\mathrm{tfc})_{3} \delta=6.50$ and 5.60 broad signals (enantiomeric protons), $e e=50 .[\alpha]_{\mathrm{D}}{ }^{22}=+11.1$. In toluene, yield $352 \mathrm{mg}(96 \%)$, solid. ${ }^{1} \mathrm{H}$ NMR $\left(200 \mathrm{MHz}, \mathrm{CDCl}_{3}\right)$, adding $\mathrm{Eu}(\mathrm{tfc})_{3} \delta=6.50$ and 5.60 broad signals (enantiomeric protons), $e e=$ 60. $[\alpha]_{D}^{22}=+13.0$.

\section{Acknowledgements}

This work was carried out within the framework of the National Project "Stereoselezione in sintesi Organica: Metodologie ed Applicazioni” supported by the Ministero dell'Istruzione, dell'Università e della Ricerca, Rome. We also thank the Italian Consiglio Nazionale delle Ricerche (CNR), Rome and the University of Lecce for financial support.

\section{References}

1. (a) Bradamante, S.; Pagani, G. Pure Appl. Chem. 1989, 61, 709 and references therein cited;

(b) Hogen-Esch, T. E.; Jenkins, W. L. J. Am. Chem. Soc. 1981, 103, 3666.

2. (a) Florio, S.; Troisi, L. Tetrahedron Lett. 1992, 33, 7953. (b) ibid. 1994, 35, 3175. (c) Florio, S.; Troisi, L.; Capriati, V.; Suppa, G. Eur. J. Org. Chem. 2000, 22, 3793.

3. Florio, S.; Troisi, L.; Capriati, V.; J. Org. Chem. 1995, 60, 2279.

4. Florio, S.; Granito, C.; Ingrosso, G.; Troisi, L.; Eur. J. Org. Chem. 2002, 20, 3465.

5. Capriati, V.; Florio, S.; Ingrosso, G.; Granito, C.; Troisi, L. Eur. J. Org. Chem. 2002, 3, 478.

6. (a) Wittig, G.; Löhmann, L. Liebigs Ann. Chem. 1942, 550, 260. (b) Schöllkopf, U. Angew. Chem. Int. Ed. 1970, 9, 763. (c) Marshall, J. A. In Comprehensive Organic Synthesis; Trost, B. M.; Fleming, I.; Eds; Pergamon Press: London, 1991; Vol. 3, p 975. (d) Tomooka, K.; Nakai, T. J. Synth. Org. Chem. Jpn. 1996, 54, 1000. (e) Yamamoto, H.; Tomooka, K.; T. Nakai, Liebigs Ann. /Recueil 1997, 1275. 
7. Nakai, T.; Mikami, K. Organic React. 1994, 46, 105. (b) Nakai, T.; Tomooka, K. Pure Appl. Chem. 1997, 69, 595 and references therein cited.

8. Kurono, N.; Sugita, K.; Tokuda, M.; Tetrahedron 2000, 56, 847.

9. Falck, J. R.; Barma, D. K.; Mioskowski, C.; Schlama, T. Tetrahedron Lett. 1999, 40, 2091.

10. Tomooka, K.; Wang, L. F.; Komine, N.; Nakai, T. Tetrahedron Lett. 1999, 40, 6813.

11. Marshall, J. A.; Adams, N. D. J. Org. Chem. 1999, 64, 5201.

12. Tsubuky, M.; Kamata, T.; Nakatani, M.; Yamazaki, K.; Matsui, T.; Honda, T. Tetrahedron: Asymmetry 2000, 11, 4725.

13. Suffert, J. J. Org. Chem. 1989, 54, 509. 